\title{
MICROBIOLOGICAL QUALITY OF OYSTERS (CRASSOSTREA GIGAS) PRODUCED AND COMMERCIALIZED IN THE COASTAL REGION OF FLORIANÓPOLIS - BRAZIL
}

\author{
Murilo Anderson Pereira; Márcia Menezes Nunes; Leonardo Nuernberg; Denys Schulz; \\ Cleide Rosana Vieira Batista*
}

Departamento de Ciência e Tecnologia de Alimentos, Universidade Federal de Santa Catarina, Florianópolis, SC, Brasil

Submitted: August 09, 2005; Returned to authors for corrections: January 23, 2006; Approved: February 26, 2006

\begin{abstract}
Oysters are filter feeders able to ingest particles in suspension that may carry pathogenic microorganisms. In this respect, the consumption of raw oysters can cause foodborne diseases in humans. The aim of the present study was to evaluate the microbiological quality of Crassostrea gigas oysters cultivated and commercialized in the coastal region of Florianópolis, SC, Brazil. The study comprised counts of coliforms at $35^{\circ} \mathrm{C}$ and at $45^{\circ} \mathrm{C}$, Escherichia coli and coagulase-positive staphylococci, and detection of Salmonella sp, Vibrio cholerae and Vibrio parahaemolyticus. Ninety samples were analyzed, 45 of them collected at seafood commercial establishments and the other 45 were collected in the cultivation area. All analyses were performed according to methods of the American Public Health Association. Vibrio cholerae, V. parahaemolyticus and Salmonella sp. were not detected in any of the samples. Coagulase-positive staphylococci were observed in only one sample $(80 \mathrm{CFU} / \mathrm{g})$. The counts of coliforms at 35 and $45^{\circ} \mathrm{C}$ indicated that samples obtained from both the cultivation area and place of sale were contaminated. E. coli was detected in $4(9 \%)$ samples collected in the cultivation area and in 16 (35.5\%) samples obtained from commercial establishments. These results indicate the need for monitoring the quality of raw oysters, including the implantation of programs for good mollusk manipulation and management practices.
\end{abstract}

Key words: coliforms, Escherichia coli, food, microbiological quality, oysters

\section{INTRODUCTION}

Bivalves feed on organic and inorganic matter, phytoplankton and particles in suspension present in water by means of branchial filtration. According to the International Commission on Microbiological Specifications for Foods (9), a single oyster can filter up to 10 liters of water/hour, thus removing particles, microorganisms and pollutants from the water into the mollusc.

There are two groups of bacteria relevant to public health that contaminate marine products: bacteria naturally present in the environment such as Aeromonas hydrophila, Clostridium botulinum, Vibrio parahaemolyticus, V. cholerae, V. vulnificus, and Listeria monocytogenes, and Enterobacteriaceae such as Salmonella sp., Shigella sp. and Escherichia coli originating from the contamination of water with human residues. The determination of coliforms of fecal origin and $E$. coli provides safe information regarding the hygiene-sanitary conditions of both the oysters and the cultivation water, since $E$. coli accounts for $90 \%$ of fecal coliforms and is an indicator microorganism of fecal contamination (10).

Oysters are usually consumed raw and in this case the molluscs are ingested as a whole, thus leading to the transmission of potentially pathogenic microorganisms to the consumer, a fact that increases the risk of foodborne diseases especially when these molluscs originate from contaminated areas or are handled under precarious hygiene-sanitary conditions. The diseases caused by the ingestion of contaminated molluscs can be of bacterial, parasitic or viral origin. In the United States, about $70 \%$ of deaths due to

*Corresponding Author. Mailing address: Departamento de Ciência e Tecnologia de Alimentos, Universidade Federal de Santa Catarina, Rod. Admar Gonzaga, 1346, Itacorubi. 88034-001, Florianópolis, SC, Brasil. Tel.: (+5548) 3331-5380, Fax: (+5548) 3331-9943. E-mail: cbatista@mbox1.ufsc.br 
foodborne diseases are of bacterial origin, with Salmonella being the main cause of death, followed by Listeria monocytogenes, Campylobacter sp. and E. coli $\mathrm{O} 157: \mathrm{H} 7$ (4).

In view of the above facts, the objective of the present study was to evaluate the microbiological quality of oysters (Crassostrea gigas) cultivated and commercialized in the coastal region of Florianópolis, Santa Catarina, Brazil.

\section{MATERIALS AND METHODS}

\section{Sampling}

Between 2003 and 2004, 90 oyster samples (Crassostrea gigas) obtained from three different cultivation areas, Sambaqui (area 1), Cacupé (area 2) and Ribeirão da Ilha (area 3), located at distinct points along the coastal region of Florianópolis, were analyzed (Fig. 1).

The oyster samples were collected from the cultivation areas and from points of sale, being 15 samples from the cultivation area and 15 from the place of sale. Thus, 30 samples were obtained from each of the three areas, with one sampling unit consisting of 12 oysters.

After collection, the oysters were stored in isothermic boxes containing dry ice until their arrival at the Laboratory of Food Microbiology, Department of Food Science and Technology,

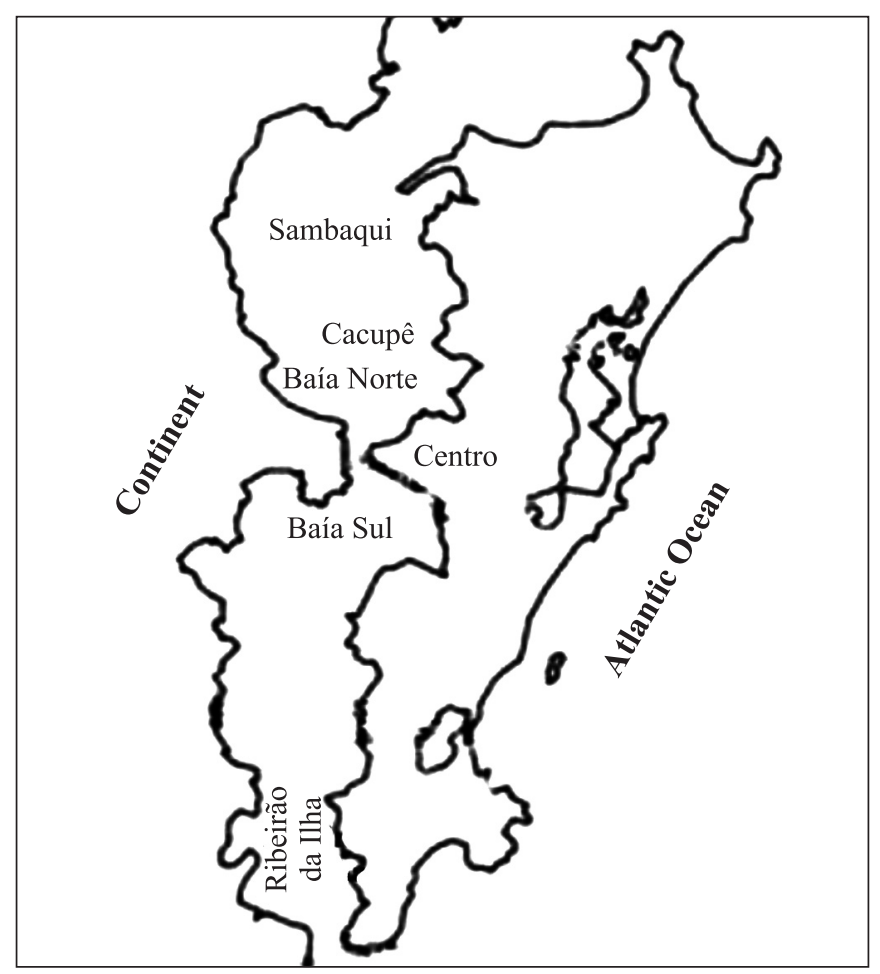

Figure 1. Map of Florianópolis showing the three oyster cultivation areas.
Federal University of Santa Catarina, where they were submitted to microbiological analysis.

\section{Microbiological analysis}

The oyster samples were submitted to enumeration of coliforms at $35^{\circ} \mathrm{C}$ and at $45^{\circ} \mathrm{C}$, E. coli and coagulase-positive staphylococci, and to the detection of Salmonella sp., Vibrio cholerae and V. parahaemolyticus.

\section{Sample preparation}

The oysters were washed with a brush and water under pressure to remove all material adhered to the shells, and then placed on a stainless-steel trays for air drying.

The oysters were removed from their shell with a sterile stainless-steel instrument appropriate for oyster opening. The intervalvar fluid and the meat were transferred aseptically to sterile bags appropriate for disintegration in a Bagmixer blender (Interscience, France).

\section{Enumeration of Coliforms at $35^{\circ} \mathrm{C}$, and at $45^{\circ} \mathrm{C}$ and Escherichia coli (1)}

Twenty-five grams of the sample were weighed, $225 \mathrm{~mL} 0.1 \%$ peptone water was added, and the mixture was disintegrated in a Bagmixer blender. Further dilutions $\left(10^{-2}, 10^{-3}\right)$ were then prepared from this dilution, and $1 \mathrm{~mL}$ of each dilution was inoculated into each tube of a series of three tubes containing $10 \mathrm{~mL}$ lauryl sulfate tryptose broth (LST). The tubes were incubated at $35^{\circ} \mathrm{C}$ for 48 hours.

All LST tubes that showed turbidity and gas production were selected and $100 \mu \mathrm{L}$ were transferred to tubes containing $2 \%$ Brilliant green lactose broth (BGL) and E. coli broth (EC). Tubes with BGL were incubated at $35^{\circ} \mathrm{C}$ for 48 hours and tubes with EC were incubated in a water bath at $45.5^{\circ} \mathrm{C}$ for 48 hours. BGL tubes with turbidity and gas production were quantified, and the most probable number (MPN) of coliforms per gram was determined using the MPN table for three tubes. The cultures in EC broth showing turbidity and gas production were streaked on eosin-methylene blue agar (EMB), and incubated at $35^{\circ} \mathrm{C}$ for 24 hours. Typical E. coli colonies were submitted indole, methyl red, Voges Proskauer and citrate (IMViC) biochemical tests.

\section{Detection of Salmonella sp. (1)}

For detection of Salmonella sp., $25 \mathrm{~g}$ of the sample was homogeneized with $225 \mathrm{~mL}$ of buffered peptone water in a Bagmixer blender. For pre-enrichment the mixture was incubated at $35^{\circ} \mathrm{C}$ for 24 hours. Aliquots of the pre-enrichment broth were transferred to tetrathionate broth (TTB) and RappaportVassiliadis (RV) broth and incubated at $35^{\circ} \mathrm{C}$ and $42^{\circ} \mathrm{C}$ for 24 hours, respectively. The selective enrichment cultures were streaked on the surface of hektoen enteric (HE), SalmonellaShigella (SS) and xylose lysine deoxycholate (XLD) agars and 
incubated at $35^{\circ} \mathrm{C}$ for 24 hours. Typical Salmonella sp. colonies were submitted to biochemical screening on triple sugar iron agar (TSI), lysine iron agar (LIA) and urea agar (UA). Colonies suspected to be Salmonella were analyzed by complementary serological and biochemical tests (dulcitol, indole, malonate, MRVP - Methyl Red Voges Proskauer, and citrate).

\section{Enumeration of coagulase-positive staphylococci (1)}

Twenty-five grams of each sample were weighed, $225 \mathrm{~mL}$ $0.1 \%$ peptone water was added, and the mixture was disintegrated in a Bagmixer blender. Further dilutions $\left(10^{-2}, 10^{-3}\right)$ were then prepared from this dilution. One milliliter of each of the first three dilutions was divided on the surface of three Baird-Parker agar (BP), plates and incubated at $35^{\circ} \mathrm{C}$ for 48 hours. Three typical colonies were selected for catalase and coagulase tests. Results were expressed as coagulase-positive staphylococci/g. When the coagulase reaction was negative, the result were is reported as $<10 \mathrm{CFU} / \mathrm{g}$.

\section{Detection of Vibrio cholerae (1)}

For the detection of $V$. cholerae, $50 \mathrm{~g}$ of the sample was weighed and $450 \mathrm{~mL} 0.1 \%$ peptone water supplemented with $1 \% \mathrm{NaCl}$ was added. The mixture was then disintegrated in a Bagmixer blender, and divided in two aliquots of $250 \mathrm{~mL}$, one incubated at $35^{\circ}$ and the other at $42^{\circ} \mathrm{C}$. After $6 \mathrm{~h}$ and $18 \mathrm{~h}$ of incubation, aliquots of each portion were streaked on two plates containing thiosulfate-citrate-bile salts-sucrose agar (TCBS). After incubation at $35^{\circ} \mathrm{C}$ for 24 hours, typical colonies were submitted to biochemical screening on Kligler iron agar (KIA), TSI and UA.

\section{Detection of Vibrio parahaemolyticus}

For the detection of V. parahaemolyticus, $50 \mathrm{~g}$ of the sample was weighed, $450 \mathrm{~mL} 0.1 \%$ peptone water supplemented with $3 \% \mathrm{NaCl}$ was added and the mixture was disintegrated in a Bagmixer blender. Decimal dilutions up to $10^{-4}$ were prepared from this dilution and $1 \mathrm{~mL}$ of each dilution was inoculated into one tube of a series of three tubes containing $0.1 \%$ peptone water supplemented with $3 \% \mathrm{NaCl}$. The tubes were incubated at $35^{\circ} \mathrm{C}$ for 48 hours. Cultures showing growth were streaked on TCBS plates and incubated at $35 \mathrm{C}$ for 24 hours. Typical colonies were submitted to biochemical screening on TSI, LIA and UA supplemented with $3 \% \mathrm{NaCl}$.

\section{Statistical analysis $(\mathbf{8})$}

The non parametric Kruskal-Wallis test with an error probality of $\alpha=0.10$ was used to compare the results of coliforms at $35^{\circ} \mathrm{C}$ and at $45^{\circ} \mathrm{C}$ in the three cultivation areas. The same test was used to compare results in the cultivation areas and the places of sale. When tests were significant for more than two areas, pairwise comparisons with an error probability of $\alpha=0.20$ were performed. For $E$. coli contaminated samples, results for the three cultivation areas were compared by means of the two proportion testes, with an error probability of $\alpha=0.10$. The same test were used to compare results in the cultivation areas and in the places of sale.

\section{RESULTS AND DISCUSSION}

None of the 90 samples analyzed was contaminated with Salmonella sp., V. cholerae or V. parahaemolyticus. In agreement with these results, Ripabelli et al. (11), analyzing 62 mollusc samples from the Adriatic Sea and searching for the presence of verotoxigenic Vibrio, Salmonella and E. coli, detected no Salmonella strains. Salmonella was also absent in oyster samples studied by Eyles and Davey (6). On the other hand, Vibrio sp. was isolated from $48.4 \%$ of the samples analyzed by Ripabelli et al. (11), with the most frequent species being $V$. alginolyticus (32.2\%) and V. vulnificus (17.7\%), while contamination with V. parahaemolyticus $(1.6 \%)$ and V. cholerae $(1.6 \%)$ was low. Eyles and Davey (6) isolated V. cholerae in 20, 30 and $11 \%$ of oysters, water and sediment samples, respectively. Vibrio parahaemolyticus was also isolated from 16 (100\%) closed oyster samples obtained directly from the producers and from 13 (93\%) open samples obtained from the places of sale (5).

In this study, only one of the 90 oyster samples was contaminated with coagulase-positive staphylococci, but the number $(80 \mathrm{CFU} / \mathrm{g})$ was lower than the limit established by the RDC 12/ANVISA, Brazil, for raw oysters, which is $10^{3} \mathrm{CFU} / \mathrm{g}$ (3). However, in a study conducted in the coastal region of Santa Catarina, Ayulo et al. (2) observed a 20\% contamination rate with Staphylococcus aureus of fish, crab, shrimp and bivalve meat samples. These authors detected that $60 \%$ of the bivalve meat samples contained coagulase positive $S$. aureus.

The counts of coliforms at $35^{\circ}$ and $45^{\circ} \mathrm{C}$ in the oyster samples are shown in Tables 1,2 and 3. The counts of coliforms at $35^{\circ} \mathrm{C}$ in samples obtained from the cultivation areas 1 and 3 were significantly lower than in samples from area 2 , while no difference was observed between areas 1 and 3. There was also no difference in the contamination level of the samples obtained from the places of sale in the three areas. Results also showed that in area A, the samples obtained from the cultivation area 1 were less contaminated than those derived from the place of sale.

In contrast, counts of coliforms at $45^{\circ} \mathrm{C}$ in oysters obtained from the cultivation area in the three areas studied presented no significant difference. However, oysters obtained from the place of sale in areas 2 and 3 were less contaminated than those in area 1 . This finding is probably due to the fact that area 1 is located in a bay that receives domestic and industrial effluents containing fecal residues. Inadequate storage of the oysters during the period between collection and sale may also have contributed to the high counts. 
Table 1. Counts of coliforms at $35^{\circ} \mathrm{C}$ and $45^{\circ} \mathrm{C}$ in oysters (Crassostrea gigas) collected from the cultivation area and place of sale in area $1 *$.

\begin{tabular}{rcccc}
\hline & \multicolumn{2}{c}{$\begin{array}{c}\text { Coliforms at } 35^{\circ} \mathrm{C} \\
(\mathrm{MPN} / \mathrm{g})\end{array}$} & $\begin{array}{c}\text { Coliforms at } 45^{\circ} \mathrm{C} \\
(\mathrm{MPN} / \mathrm{g}) * *\end{array}$ \\
\cline { 2 - 5 } & Cultivation & Sale & Cultivation & Sale \\
\hline 1 & 28 & 93 & 11 & 75 \\
2 & 28 & 21 & 20 & 15 \\
3 & 93 & 28 & 23 & 11 \\
4 & 23 & 1100 & $<3$ & 150 \\
5 & $<3$ & 23 & $<3$ & 15 \\
6 & 4 & 93 & $<3$ & 4 \\
7 & 4 & 43 & $<3$ & 9 \\
8 & $<3$ & 1100 & $<3$ & 1100 \\
9 & $<3$ & 93 & $<3$ & 23 \\
10 & 23 & 4 & $<3$ & $<3$ \\
11 & $<3$ & 4 & $<3$ & 4 \\
12 & $<3$ & $<3$ & $<3$ & 9 \\
13 & $<3$ & $<3$ & $<3$ & $<3$ \\
14 & $>1100$ & $>1100$ & $>1100$ & $>1100$ \\
15 & $<3$ & 15 & $<3$ & 15 \\
\hline
\end{tabular}

(*) Sambaqui, (**) Most probable number per gram sample.

Table 2. Counts of coliforms at $35^{\circ} \mathrm{C}$ and $45^{\circ} \mathrm{C}$ in oysters (Crassostrea gigas) collected from the cultivation area and place of sale in area $2^{*}$.

\begin{tabular}{rcccc}
\hline & \multicolumn{2}{c}{$\begin{array}{c}\text { Coliforms at } 35^{\circ} \mathrm{C} \\
(\text { MPN/g)** }\end{array}$} & \multicolumn{2}{c}{$\begin{array}{c}\text { Coliforms at } 45^{\circ} \mathrm{C} \\
(\mathrm{MPN} / \mathrm{g}) * *\end{array}$} \\
\cline { 2 - 5 } & Cultivation & Sale & Cultivation & Sale \\
\hline 1 & 93 & 150 & 93 & 75 \\
2 & 93 & 1100 & 21 & 1100 \\
3 & 240 & 23 & 21 & $<3$ \\
4 & 9 & 43 & 9 & $<3$ \\
5 & 210 & 1100 & 20 & $<3$ \\
6 & 9 & 43 & $<3$ & $<3$ \\
7 & 9 & 4 & $<3$ & $<3$ \\
8 & 1100 & 4 & $<3$ & $<3$ \\
9 & 43 & 93 & $<3$ & 23 \\
10 & 9 & 460 & $<3$ & 240 \\
11 & 9 & 93 & $<3$ & $<3$ \\
12 & 4 & $<3$ & $<3$ & $<3$ \\
13 & 7 & 21 & $<3$ & 21 \\
14 & 9 & 21 & $<3$ & 21 \\
15 & $<3$ & $<3$ & $<3$ & $<3$ \\
\hline
\end{tabular}

(*) Cacupé, (**) Most probable number per gram sample.
Table 3. Counts of coliforms at $35^{\circ} \mathrm{C}$ and $45^{\circ} \mathrm{C}$ in oysters (Crassostrea gigas) collected from the cultivation area and place of sale in area $3 *$.

\begin{tabular}{rcccc}
\hline & $\begin{array}{c}\text { Coliforms at } 35^{\circ} \mathrm{C} \\
(\mathrm{MPN} / \mathrm{g}) * *\end{array}$ & \multicolumn{2}{c}{$\begin{array}{c}\text { Coliforms at } 45^{\circ} \mathrm{C} \\
(\mathrm{MPN} / \mathrm{g})\end{array}$} \\
\cline { 2 - 5 } & Cultivation & Sale & Cultivation & Sale \\
\hline 1 & 3 & 43 & $<3$ & 43 \\
2 & 150 & 150 & 93 & 75 \\
3 & 28 & 240 & 11 & 150 \\
4 & 15 & 4 & 7 & $<3$ \\
5 & 4 & 9 & $<3$ & $<3$ \\
6 & 7 & 23 & $<3$ & 9 \\
7 & 7 & 4 & $<3$ & $<3$ \\
8 & 15 & 4 & $<3$ & $<3$ \\
9 & 4 & 4 & $<3$ & $<3$ \\
10 & 4 & 4 & $<3$ & $<3$ \\
11 & $<3$ & $<3$ & $<3$ & $<3$ \\
12 & $<3$ & $<3$ & $<3$ & $<3$ \\
13 & $<3$ & $<3$ & $<3$ & $<3$ \\
14 & 21 & $<3$ & 15 & 4 \\
15 & $<3$ & $>1100$ & $<3$ & 4 \\
\hline
\end{tabular}

(*) Ribeirão da Ilha, (**) Most probable number per gram sample.

Regarding the contamination with coliforms grown at $45^{\circ} \mathrm{C}$ of oysters obtained from the cultivation area and place of sale, samples from area 1 collected in the cultivation area were less contaminated than those obtained from the place of sale, a finding suggesting precarious conditions of manipulation and inadequate storage of the oysters during the period between collection and sale. According to Jay (10), ambient temperature $\left(25^{\circ} \mathrm{C}\right)$ provides better conditions for microbial multiplication in foods.

The microbiological limit for coliforms at $45^{\circ} \mathrm{C}$ established by RDC 12/ANVISA for oysters is $\leq 50 \mathrm{MPN} / \mathrm{g}$ (3). The counts of coliforms at $45^{\circ} \mathrm{C}$ in oyster samples collected in the three cultivation areas where higher than this limit: 6.7\% (3/45) in samples collected at the producers and 20\% (9/45) in samples obtained from the places of sale.

E. coli (Table 4) was detected in 9\% (4/45) of oyster samples collected in the cultivation area, and in 35.5\% (16/45) of samples obtained from commercial establishments. Eyles and Davey (6) detected E. coli in $43 \%$ of all samples, and Ayulo et al. (2) reported contamination with $E$. coli in $37.7 \%$ of fish, crab, shrimp and bivalve meat samples. This high prevalence of $E$. coli agrees with the present results.

The hygiene-sanitary quality of oysters at the place of sale in areas 1 and 2 was significantly lower than that of oysters collected in the cultivation area $(\alpha=0.05)$. This difference is 
Table 4. Presence of Escherichia coli in oysters (Crassostrea gigas) collected from the cultivation area and place of sale in the three areas analyzed.

\begin{tabular}{ccc}
\hline \multirow{2}{*}{ Area } & \multicolumn{2}{c}{ Escherichia coli } \\
\cline { 2 - 3 } & Cultivation * & Sale* \\
\hline 1 & $1 / 15$ & $8 / 15$ \\
2 & $1 / 15$ & $5 / 15$ \\
3 & $2 / 15$ & $3 / 15$ \\
\hline Total & $4 / 45$ & $16 / 45$ \\
\hline
\end{tabular}

(*) Number of positive samples/number of samples analyzed.

probably due to the inadequate storage of oysters between collection and sale of the product. The difference in contamination with $E$. coli of the three oyster cultivation areas was not significant $(\alpha=0.05)$.

Since oysters are frequently consumed raw and $E$. coli is an indicator of fecal contamination, with potentially pathogenic serogroups being involved in diseases such as hemorrhagic colitis and uremic-hemolytic syndrome, the consumption of raw oysters poses a high risk to consumers health $(7,10)$. The presence of coliforms grown at $45^{\circ} \mathrm{C}$ and $E$. coli, especially at the places of sale, indicates the need for monitoring the quality of raw oysters, including the implementation of programs for good mollusk manipulation and management practices.

\section{RESUMO}

\section{Qualidade microbiológica de ostras (Crassostrea gigas) produzidas e comercializadas na região litorânea de Florianópolis - Brazil}

A ostra é um filtrador capaz de ingerir partículas em suspensão, as quais podem carrear microrganismos patogênicos. Desta forma, o hábito de consumir ostras cruas pode causar toxinfecções alimentares em humanos. O presente trabalho teve como objetivo avaliar a qualidade microbiológica de ostras da espécie Crassostrea gigas cultivadas e comercializadas na região litorânea de Florianópolis, através da contagem de coliformes a $35^{\circ} \mathrm{Ce} 45^{\circ} \mathrm{C}$, Escherichia coli e estafilococos coagulase positiva e da pesquisa de Salmonella sp, Víbrio cholerae e Víbrio parahaemolyticus. Foram analisadas 90 (noventa) amostras das quais 45 foram coletadas em estabelecimentos comerciais destinados à venda de frutos do mar e 45 coletadas diretamente do local de cultivo. Todas as análises foram realizadas de acordo com métodos da American Public Health Association. Vibrio cholerae, Víbrio parahaemolyticus e Salmonella sp. não foram encontrados em nenhuma das amostras. Apenas uma amostra apresentou $80 \mathrm{UFC} / \mathrm{g}$ de estafilococos coagulase positiva, as demais amostras apresentaram $<10 \mathrm{UFC} / \mathrm{g}$. Com o resultado das contagens de coliformes a $35^{\circ} \mathrm{C}$ e a $45^{\circ} \mathrm{C}$, evidencia-se contaminação tanto no local de cultivo quanto no local de venda. Escherichia coli foi encontrada em $4(9 \%)$ das amostras provenientes do local de cultivo e em $16(35,5 \%)$ amostras coletadas nos estabelecimentos comerciais. Estes resultados indicam a necessidade de se monitorar a qualidade de ostras cruas, com a implantação de programas de boas práticas de manipulação e manejo dos moluscos.

Palavras-chave: coliformes, Escherichia coli, alimentos, qualidade microbiológica, ostras

\section{REFERENCES}

1. American Public Health Association (APHA). Compendium of methods for the microbiological examination of foods. vol. 4. D.C., Washington, 2001, 1219p.

2. Ayulo, A.M.R.; Machado, R.A.; Scussel, V.M. Enterotoxigenic Escherichia coli and Staphylococcus aureus in fish and seafood from the southern region of Brazil. Int. J. Food Microbiol., 24, 171178,1994

3. Brasil. Resolução RDC n ${ }^{\circ} 12$, de 2 de janeiro de 2001. Aprova o regulamento técnico princípios gerais para estabelecimento de critérios e padrões microbiológicos para alimentos e seus anexos I, II e III. Diário Oficial. Brasília, 10 de janeiro de 2001.

4. Centers for Disease Control and Prevention (CDC). Multistate outbreak of listeriosis. Morbid. Mortal. Weekly Rpt, 49, 1129-1130, 2000.

5. Eyles M.J.; Davey, G.R.; Arnold, G. Behavior and incidence of Vibrio parahaemolyticus in Sydney rook oysters (Crassostrea commercialis). Int. J. Food Microbiol., 1, 327-334, 1985.

6. Eyles M.J.; Davey G.R. Vibrio cholerae and enteric bacteria in oysterproducing areas of two urban estuaries in Australia. Int. J. Food Microbiol., 6, 207-218, 1988.

7. Frazier W.C. and Westhoff D.C. (ed.). Microbiología de los alimentos. vol. 4, Acribia, Zaragoza, 1993, 465p.

8. Freund J.E. and Simon G.A. (ed.). Estatística Aplicada. vol. 9. Porto Alegre, 2000, 404p.

9. International Commission on Microbiological Specifications for Foods (ICMSF). Ecologia Microbiana de los Alimentos. vol. 2. Zaragoza, Spain, 1985, p.573-608.

10. Jay J.M. (ed.). Modern Food Microbiology. vol. 6. Aspen Publishers, 2000, 620p.

11. Ripabelli G.; Sammarco, M.L.; Grasso, G.M.; Fanelli, I.; Caprioli, A.; Luzzi, I. Occurrence of Vibrio and other pathogenic bacteria in Mytilus galloprovincialis (mussels) harvested from Adriatic Sea, Italy. Int. J. Food Microbiol., 49, 43-48, 1999. 